\title{
The Effects of Student's Perception on Role Play Technique and Student's Learning Motivation on Speaking Skills
}

\author{
Sufi Alawiah' ${ }^{1}$, Suwarsito² \\ ${ }^{1}$ ABA BSI Jakarta \\ Email: sufi.sfy@bsi.ac.id \\ ${ }^{2}$ AMIK BSI Bogor \\ Email: suwarsito.swr@bsi.ac.id
}

\begin{abstract}
This research is a kind of survey and aims to find out and analyze empirically the effects of student's perception on role play and students' learning motivation on speaking skills. The observed population of this research is IX grade students of State Junior High School, North Jakarta, which total of 195 students. The samples are 66 students which are divided evenly 11 students per class. The collection of the data is done by questionnaire and objective test for independent and dependent variables. The gained data was then analyzed by using correlation technique and double linier regression. The result of this research are: 1)There is a significant effect of student's perception on role play method and learning motivation jointly on student's speaking skill, based on the ANOVA table, the sig. value revealed is 0.000 which is lower than 0.05 . Since sig. value $<0.05 ; 2$ ) There is a significant effect of student's perception on role play method on students' speaking skill, since t value $>t(2.999$ > 1.998); 3) There is a significant effect of learning motivation on students' speaking skill, since $t$ value $>t(5.119>1.998)$. The findings of the research shows that all indicators for student's perception on role play, motivation and speaking skill variables are valid and reliable.
\end{abstract}

Keywords: Learning motivation, speaking skill, motivation and speaking skill

\section{INTRODUCTION}

English teachers teach English as a tool to communicate orally and in writing. To communicate is to understand and express information, thoughts, feelings, and to develop science, technology, and culture. Ability to communicate in a full understanding is the ability to discourse, consisted of the ability to understand and/or produce spoken text and/or written which is realized in the four language skills, namely listening, speaking, reading and writing. These skillsare used to respond to or create a discourse in public life.

Competency Standards and Competencies Basic SMP states that English subjects is directed to develop these skills (listening, speaking, reading and writing) so that graduates are able to communicate and to produce discourse in English at a certain level of literacy (Badan Standar Pendidikan Nasional, 2006:129).

English literacy levels comprised of performative, functional, informational, and epistemic. At the performative level, people are able to read, write, listen, and speak with the symbols used. At the functional level, people are able to use language to meet the needs of daily living such as reading newspapers, manuals or instructions. At the informational level, people are able to access the knowledge of the language, while at the epistemic level of people able to express knowledge in the target language (Badan Standar Pendidikan Nasional, 2006:129).

261 Junior High School is located at Muara Angke fishermen residential area whereas the students having various background and a wide range of social status, mostly middle class and below. Level of Intellectual ability is poor, while harsh social characters tend to require hard work for the educators to develop their characters, more polite in the order of ethics and aesthetics of behavior in their daily lives. Though in their daily life, English is not an important issue, yet with the rapidly increasing globalization, the dominance of English as a language of communication is inavoidable. In 2010 the estimated number of people who used English as a foreign language or second language will exceed it's native speaker. Also with the enactment of AFTA (Asean Free Trade Area) and AFLA (Asean Free Labour Area).

One method of learning English is the Role play method. Role play is a kind of motion games in which there is purpose, rules while simultaneously involves excitement. In this method, the students is situatedin certain condition outside of the classroom, while the method itself take place in the classroom learning, using the English language. Role Play is often intended as a form of activity in which the learners imagine themselves as if they were outside 
the classroom and play the role of others when using English.

The study is comprised of two subjects, the students and the teacher. Learning processes and outcomes are influenced by students' interest and motivation. Motivation to learn can arise because of the external attractiveness (encouragement from the guidance of teachers, parents, friends, environment) or from within the student (motivation to excell, desire for a scholarship, etc.), the teacher must be able to apply teaching methods that motivates students to learn and monitors the implementation efforts to improve student learning outcomes

Based on the explanation above, the witer will emphasize the problem related to the effect of perception of role play and learning motivation towards speaking skills that will be discussed on this paper entitled " The Effects of Student's Perception on Role Play Techniqueand and Learning Motivation on Student's Speaking Skills”

\section{Role Play}

\section{a. Definition of Role Play}

The activity of study is done by two persons which are the teacher and the student. The teachers teach while the students study. In this activity learning is dealt with finding the best learning model to be tested and further developed in the learning activities. All learning methods is developed to enhance the quality of learning.

Strategy as according to Kemp is a learning activitiy which must be carried out by the teacher and the students to fulfil the objective of the study effectively and efficient. While Kemp, Dick and Carey (1985) said that learning strategy is a set of learning material and prosedures to be used in conjuction to exert a certain result on the student (Rusman, 2012:132).

To implement learning program, a method is required. A certain strategy may implement several methods, such as expository that used narration and discussion on a certain topic. Strategy dealt with a planning to reach a certain objective, - a plan of operation achieving something; while method is a way in achieving something (Rusman, 2012:132).

Role play method in the learning process is used to learn about the introduction of the feelings and problems faced by students, and to develop problemsolving ability. Role play techniques aimed at solving problems involving human relationships, particularly with respect to students' lives and to motivate students to pay more attention to the material being taught.

Role play is a simulation of the behavior of those characters in play, this meant to train students in real situations; to train them intensively oral language, and provide opportunities for students to develop communication skills. Joyce and Weil (2007: 70) explains that with role play, students can improve their ability for self-respect and feelings of others, they can learn good behavior for handling difficult situations, and they can practice their skills in problem solving

Role-play is an useful tool since through this activity, more cognitive demands on learners' comprehension and production system are made and learners' ability to instantaneously incorporate sociopragmatic and pragmalinguistic knowledge in interaction are examined. This technique is virtually one of the ways we can give our learners the opportunity to practice improving a range of real-life spoken language in the classroom (Aliakbari and Jamalvandi, 2010:20).

In their study, Platt and Brooks (1994) studied the interpretation of role-play by two different groups which revealed that, one group simply carried out the instructions in a mechanical fashion while the other group reconstructed the task in accordance with their own goals. They managed to show that the kind of talk produced by two groups differed greatly. with far more metatalk evident in the second (Aliakbari and Jamalvandi, 2010:20). Najizade (1996) concluded that role-play as an activity for bringing real language situations into classroom was considerably effective in improving subjects' acquiring the foreign language structures (Aliakbari and Jamalvandi, 2010:20).

In concept, role play is very applicable to the activity of CTL in the classroom teaching and learning as a teaching technique for speaking. Role play can attract students since it's provide the opportunity to practice speaking in a language they are learning in real situations of communication.

"Role play is drama like classroom activities in which students take role of the defferent participants in a situation and act out what might typically happen in that situation" (Richard, Jack, Platt, John, weber, Heidi, 1985:246)

A well used role play can reduce the artificiality of the classroom, provide a reason for talking and allow the learner to talk meaningfully to other learners. Role play differ from the controlled practice of the dialogue or dialogue with slots for the learners to substitute alternatives. It has the element of freedom and possibility of surprise.

Role play method is one of the learning process in the category of simulation method. According to Dawson, as quoted by Moedjiono \& Dimyati, simulation is a generic term relating to organization and operation of a model that replicates the processes 
of behavior. Meanwhile, Ali argued that simulation method is a way of teaching by making the imitation of behavioral processes.

Simulation teaching method is divided into 3 groups, as proposed by Ali quoted from ProIbid, namely: (a) sociodramatic, a kind of social drama to embed the ability to analyze a particular social situation, (b) psychodrama, which is almost similar to the sociodramatic. The difference lies in the emphasis. Socio drama emphasizes on social issues, while psychodrama emphasizes on the psychological influence, and (c) Role-Playing, a method that aims to describe a past event.

Meanwhile, Moedjiono and Dimyati also divide simulation teaching methods into 3 groups as follows:

(1) Simulation games, is a game where the players act as a decision maker, acting as if they were really involved in a real situation, and/or compete to achieve specific objectives in accordance with prescribed roles for them;

(2) Role Playing, which is playing predefined roles based on previous events, intended to recreate the circumstances of history/past events, creating possibilities of future events, reproduce enriched current or imagining a particular situation in a place and/or time, and

(3) Sociodramatic (sociodrama) which is the manufacturing a group problem solving that focused on an issue related to human relations. Sociodramatic provides the opportunity for students to determine alternative solutions to problems that arise and become the group's attention.

Learning by using role play is a learning method which in a way reproducing an actual situation to gain an understanding of a concept. In this method the studentshave the opportunity to be actively involved to better understand the concepts and remember more intense.

Role play method is a method of learning in which the students pretend or imitate of the situation of historical figures in such a way. Thus role playing involves the students to pretend to play the roles/characters involved in the process of history. Role playing is a part of simulation method directed to the creatively recreate historical, actual events, or events that appear.

\section{b. Role Play benefits and advantages}

The use of role-plays in class offer the following benefits:

- Enable students to work together as a team or group, and communicate in order to understand each other, not mere simple acts of reading or reproduction of information;
- Can be adapted to the needs of the students, such as using specific situations vocabularies;

- Provide more responsibility in students' learning by encouraging interaction;

- Enable students to evaluate their learning progress and their level of English (Anne Dorathy \& Mahalakshmi, 2011:3).

There are alot of advantages both teacher and students can get from role play technique. Maley stated that role is one of a whole gamut of communicative techniques which develops fluency in language students which promote interaction in the classroom, and which increases motivation. Further, Maley tells some reasons to use role play in language class. Here is a list of the main reasons:

1. Through role play activities, a very wide variety of experience can be brought into the classroom. By using role play, the teacher can train the students in speaking skills in any situation.

2. Role play puts students in the situation in which they are required to use and develop the language.

3. Students can try out and experiment with the language in a friendly and safe environment of a classroom.

4. Role play can help many shy students by providing them with a mask. The students aredeliberated by role play as they no longer feel that their own personality is implicated.

Moreover, Wood stated that role play can also be freer or more open. The advantage of such activities is that the purpose is very clear to students and the teacher can control how much support to give them.

Referring to what has been explained above, it can be concluded that a role play is a classroom technique that encourages students to participate actively in the process of learning in which learners play a part, and experience the language in context of real life communication.

\section{Learning Motivation}

Learning processes and outcomes are influenced by students' interest and motivation. Motivation to learn can arise due to external attraction (encouragement from the guidance of teachers, parents, friends, environment) or internal from within the student (like wanting to excel, want to get a scholarship, etc.).

It is accepted for most field of learning that motivation is essensial to success: that we must willing to do something to succeed at it. Without such motivation we will almost certainly fail to make the necessary effort. We need, therefore, to develop our understanding of motivation - what it means, where it comes from and how it can be sustained.

Motivation can be described as something that energizes, directs, and sustains behavior toward a particular goal (Blerkom, 2006:14). Motivation 
affects whether or not you do your work, which study strategies you decide to use, when you do your work, how long you work on a task, how well you concentrate on it, how much effort you expand doing it, and what you learn from completing the task. The same definition of motivation is also mentioned by Krause, et.al. According to them, motivation can be thought of as an internal process that energises, directs and maintains behaviour over time. Each of these components is important. 'Energising' is what starts you off and gets you going. 'Direction' determines what you do, what choices you make or what interests you pursue, while 'maintenance' ensures that this activity continues over time (2010:262).

Motivation is what moves us to action: why we start, go on with or stop an activity; giving a motive to do something; internal processes and external incentives that spur us to satisfy a need; the response we make to challenges and threats in situations where success or failure possible; the marshalling of enthusiasm, confidence and persistence. In other word, motivation is the pilot light of learning (McLean, 2009:7).

The ways in which individuals learn languages and the outcomes of their learning efforts are influenced by a variety of individual psychological factors. These factors, icluding motivation, affective state and beliefs, describe conditions that are dependent on context or experience and therefore more amenable to change (Benson, 2001:67). This is also supported by Dressel and Marcus who said that learning is dependent upon motivation, direct sensory experiences, activities conducive to learning, and the ability to use an abstract symbolic language.

Besides the definition given by some experts above, there are other various definition of motivation that have been proposed over the course of decades of research. Following are three different perspectives of motivation:

1) From a behavioristic perspective, motivation is seen in very matter of fact terms. It is quite simply the anticipation of reward. Driven to acquire positive reinforcement, and driven by previous experiences of reward for behavior, we act accordingly to achieve further reinforcement. In this view, our acts are likely to be at the mercy of external forces.

2) In cognitive terms, motivation places much more emphasis on the individual's decisions - the choices people make as to what experiences or goals they will approach or avoid, and the degree of effort they will exert in that respect. There are six needs undergirding the construct of motivation: First, the need for exploration-for seeing or probing the unknown. Second, the need for manipulation-for operating on the environment and causing change. Third, the need for activity-for movement and exercise, both physical and mental. Fourth, the need for stimulation - the need to be stimulated by the environment, by other people, or by ideas, thoughts, and feelings. Fifth, the need for knowledge - the need to process and internalize the results of exploration, manipulation, activity, and stimulation, to resolve contradictions, to quest for solutions to problems and for selfconsistent systems of knowledge. Finally, the need for egoenhancement, for the self to be known and to be accepted and approved of by others.

3) A constructivist view of motivation places even further emphasis on social context as well as individual personal choices. Each person is motivated differently, and will therefore act on his or her environment in ways that are unique. Abraham Maslow (1970) viewed motivation as a construct in which ultimate attainment of goals was possible only by passing through a hierarchy of needs, three of which were solidly grounded in community, belonging, and social status. Maslow saw motivation as dependent on the satisfaction first of fundamental physical necessities (air, water, food) then of community, security, identity, and self-esteem, the fulfillment of which finally leads to self-actualization.

To have better understanding about these three views of motivation, it can be seen on the following table:

Table 1: Three views of motivation

\begin{tabular}{|c|c|c|}
\hline Behavioristic & Cognitive & Constructive \\
\hline $\begin{array}{l}\text { - } \begin{array}{l}\text { Anticipation of } \\
\text { reward }\end{array} \\
\text { - } \begin{array}{l}\text { Desire to } \\
\text { receive } \\
\text { positive } \\
\text { reinforcement }\end{array} \\
\text { - } \begin{array}{l}\text { External } \\
\text { individual } \\
\text { forces in } \\
\text { control }\end{array}\end{array}$ & 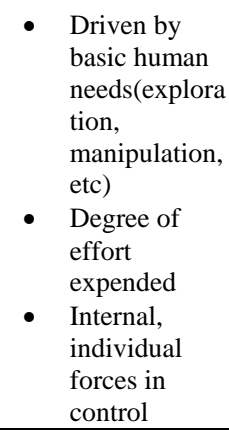 & $\begin{array}{ll}\text { - } & \text { Social context } \\
\text { - } & \text { Community } \\
\text { - } & \text { Social status } \\
\text { - } & \text { Security of } \\
& \text { groupo } \\
\text { - } & \text { Internal } \\
& \text { interactive } \\
\text { forces in } \\
\text { control }\end{array}$ \\
\hline
\end{tabular}

Motivation is all the reasons behind why we behave as we do and resolves around intentionally. We are all motivated by many different things. It is influenced by our past, present and the future.

Motivation can be defined as the power (energy) that cause one's level of persistence and enthusiasm in performing an activity, this can be derivied within the individual itself (intrinsic motivation) or from outside the individual (extrinsic motivation).

The level of motivation of the individual will determine much of the quality of the displayed behavior, both in the context of learning, work and 
other life. Study of motivation is often associated with the achievement of performance.

Abin Makmun Shamsuddin suggests that the motivation of individuals can be seen from several indicators, including: (1) the duration of the activity, (2) the frequency of activity, (3) the persistence of the activity; (4) patience, tenacity and ability in facing obstacles and difficulties; (5) devotion and sacrifice to achieve goals, (6) the level of aspiration to be achieved by the activities carried out, (7) the level of qualification achievement or product (output) is achieved from the activities carried out; (8) the attitude toward the target activity (Syamsuddin Makmun, 2003:40)

\section{Speaking skills (speaking English)}

Speaking is one of communication skills in which the speaker shares information while at the same time he/she also gets information from the listener. For most people, the ability to speak a language has often been viewed as the most demanding of the other three skills. Chaney as quoted by Ramin Rahimy (2012:8) stated that: "Speaking is the process of building and sharing meaning through the use of verbal and non-verbal symbols, in a variety of context."

By speaking someone can communicate his ideas or information, and shares them to others at any situations and in a various contexts. Brown $(1994 ; 120)$ in bailey stated that Speaking is an interactive process constructing meaning that involves producing and receiving and processing information. According to Bailey Speaking is the productive aural/oral skill which consists of producing systematic verbal utterances to convey meaning. Moreover, Dessalles explained that speaking is the process of expressing thought, idea or feeling in the form of spoken language. Based on the definitions above, speaking is the process of conveying meaning, expressing idea and feeling through verbal utterances at any situations and in various contexts.

The definition of conversational skills is the ability that is "active-productive", i.e. ability to produce or convey ideas, thoughts, or feelings by the speaker. This capability requires the "encoding", i.e. activities to convey the language to the other party orally. This activity is a take and give, that is at almost the same time the speaker member (give) the ideas to the other person's ideas and simultaneously accept (take) ideas of the other person. The interaction between the speaker and the speaker can be illustrated through the following scheme:

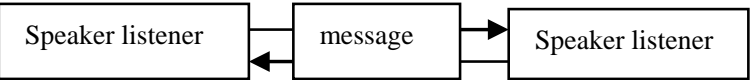

Figure 1 : speaker correlation
From this scheme can be seen that the direction of the arrow indicates the movement direction of reciprocal communication between the speakers with the listener. When someone listen to others talk (listener), when the other person may serve as speaker. While the message that will be communicated through the process of encoding presented in the form of sound symbol system (language). The change from one role to another often occurs very quickly in the form of conversation.

Speaking a language is really difficult for foreign language learners because effective oral comminication requires the skills to use the language appropriately in social interactions. Skill refers to the ability to use one's knowledge effectively in doing something.

In order to speak communicatively and effectively, one should have speaking skill. Speaking skill has to be learned, practiced and evaluated over a period of time. Speaking skill in Hyper dictionary is described as an ability to speak that has been acquired by training.

Learning to speak a foreign language requires more than knowing its grammatical and semantic rules. Learners must also acquire the knowledge ofhow to use the language in the context of structured interpersonal exchange. Therefore, the students need explicit intruction in speaking, which generally has to be learned and practiced.

Learning speaking skill is very challenging for students in foreign language context, such as in Indonesia. Students have very few opportunies to use the target language outside the classroom. That is the teacher's role to facilitate the communicative learning and teaching process so that the students can practice and improve their speaking skill.

To know the characteristic of spoken language, it's good to know the things that make how to speak is difficult. What makes it difficult to speak we can see as follows:1) explanation (clustering): speaks fluent is to speak use the same phrases (phrasal), not word for word. Students can develop cognitive language and physical (in affiliated group) in several ways (clustering), 2) abundant/solid (redundancy): the speaker has the opportunity to create meaning clearly trough language tamp. So students can emphasize the oral aspect, 3) other forms of abbreviation/reduction (reduced forms): abbreviations, removal of unnecessary, reduced vowels, and others, who all have their own problems in teaching of spoken language, 4) performance variables: one of the main advantages to use oral language is the thought process of talking provides an opportunity to manifest a number of performance hesitation, 
pause/stop, turn back, and correction (hesitation, pauses, backtracking, and corrections), 5) language the daily/association (colloquial language): make sure your students well grounded using words and idioms/expression and phrases daily language so they can practice in producing these forms, 6) rate of delivery: another characteristic of eloquence is the rate of delivery. One of the teacher task is to help the students reach speeds of revenue such as what is done by someone else/other students, 7) pressure, rhythm and intonation: a characteristic of the most to the pronunciation of English is fluent, and, 8) the interaction: learning to produce waves of language in a vacuum without the person who was invited to speak will damage speaking skills of its components: the creativity that is conversational negotiation.

\section{Hipotesis}

H1 : There is a significant effect of student's perception on role play method and learning motivation jointly on student's speaking skill.

H2 : There is an effect of student's perception on role play method on student's speaking skill.

H3 : there is an effect of learning motivation on student's speaking skill.

\section{RESEARCH METHODOLOGY}

Based on the variables studied, problem formulated and hypothesis put forth, the researcher used quantitative methods. Sugiyono (2009) defined research method as a scientific method to acquire valid data to find, prove and develop a knowledge that in turn can be used to understand, solve and anticipate a problem. Quantitative research places heavy emphasis on using formalized questions and predetermined response option in questioner of survey administered to large number of respondents. The research is cross-sectionalwhereas the data is collected during certain period of days or weeks (Kountur, 2005: 106).

This research uses Descriptive and causal design to analyze the Effect of Role Play on Students' motivation and speaking skills on IX grade students of SMPN 261, North Jakarta. Descriptive research is performed to describe the variables in the research without making comparation or correlation of the variables (Sugiyono, 2009) while causal research designs is used to analyze the effect of Role Play on Students' motivation and speaking skills.

\section{II.1 Instruments Test}

\section{a. Validity Test}

The term validity, as used in research, refers to the appropriateness, meaningfulness, correctness, and usefulness of any inferences a researcher draws based on data obtained through the use of an instrument (Fraenkel and Wallen ; 2007:150).
Validity is the extent to which an instrument measures what it is supposed to measure and performs as it is designed to perform. It is rare, if nearly impossible, that an instrument be $100 \%$ valid, so validity is generally measured in degrees. As a process, validation involves collecting and analyzing data to assess the accuracy of an instrument. The validity of each item in instruments was shown by significant correlation between item score and total score. This was shown by statistical measurement, correlation number. The correlation number must be equal or higher than required critical value.

To test the validity of items in instruments, the researcher used Corrected Item-Total Correlation, by correlating each item score with total score. The statistical table correlation coefficient used $\alpha=5 \%$ (significance at the 0,05 level) with score of $r_{\text {table }}$ on each item. If the score of $r_{\text {value }}$ is $\geq$ (equal or higher) than $r_{\text {table }}$, the instrument or each item correlates significantly with total score. In other word, the item is valid. On the other hand, if the score of $r_{v a l u e}$ is < (lower) than $r_{\text {table }}$, the instrument or each item does not correlate significantly with total score. In other word, the item is not valid. (Priyatno ; 2010:91)

The instruments used in this research had already been tested on a group of students which not include as samples before the researcher used them to get the data of this research. The instruments (vocabulary test and learning motivation questionaire) were given to 46 students from different class in order to get the data of instruments' validity and reliability.

\section{b. Reliability Test}

Reliability refers to the consistency of the scores obtained - how consistent they are for each individual from one administration of an instrument to another and from one set of items to another. (Fraenkel and Wallen ; 2007: 157) In other word, a reliable instrument or test is consistent and dependable. If the same test is given to the same student or matched students on two different occasions, the test should yield similar results.

To check the consistency of an instruments, the researcher used Cronbach Alpha Technique using SPSS 17.00 program.

\section{II.2 Classic Assumption Tests a. Test of Homogeneity}

Test of homogeneity was conducted to determine whether the data obtained from a population that have the same variance or not. The test of homogeneity in this research used the Levene's Test using SPSS 17.00 program.

The criteria in testing for homogeneity were as follow: 
$\mathrm{H}_{0}=$ If the p value (Sig.) > (higher than) 0.05, it can be concluded that the data are homogeny;

$\mathrm{H}_{1}=$ If the $\mathrm{p}$ value (Sig.) < (lower than) 0.05 then it can be concluded that the data are not homogeny. (Sulistyo ; 2012:52)

\section{b. Test of Normality}

Test of normality was conducted to determine whether the data obtained from a normally distributed population or not.

The test of normality in this research used the Kolmogorov-Smirnov test using SPSS 17.00 program.

The criteria in testing for normality were as follow:

$\mathrm{H}_{0}=$ If the $\mathrm{p}$ value (Sig.) $>$ (higher than) 0.05 , it can be concluded that the data are normally distributed;

$\mathrm{H}_{1}=$ If the $\mathrm{p}$ value (Sig.) < (lower than) 0.05 then it can be concluded that the data are not normally distributed. (Sulistyo ; 2012:50)

\section{c. Test of Linearity}

Test of linearity is to determine whether the relationship between independent and dependent variables in the form of linear or not.

The test of normality in this research used the ANOVA test using SPSS 17.00 program.

The criteria in testing for linearity were as follow:

$\mathrm{H}_{0}=$ If the $\mathrm{p}$ value (Sig.) > (higher than) 0.05 , it can be concluded that the regression line is linear.

$\mathrm{H}_{1}=$ If the $\mathrm{p}$ value (Sig.) < (lower than) 0.05 , it can be concluded that the regression line is not linear (Sulistyo ; 2012:54).

\section{II.3 Multiple Regression Linear Tests}

In order to get the data of the effects of the independent variables towards dependent variable, the R square test and F-test were used.

a. Coefficient of Determination $\left(R^{2}\right)$ Test

The accuracy of the model can be measured by the coefficient of determination $\left(\mathrm{R}^{2}\right)$ which showed a significant amount of the contribution from independent variables $\left(\mathrm{X}_{1}\right.$ and $\left.\mathrm{X}_{2}\right)$ to the dependent variable (Y).

b. F-Test

$\mathrm{F}$ test is used to determine whether the independent variables consisting of student's perception on roleplay $\left(\mathrm{X}_{1}\right)$ and learning motivation $\left(\mathrm{X}_{2}\right)$ collectively contribute to dependent variable speaking skill (Y). From ANOVA or F test, if the score of $F_{\text {value }}>F_{\text {table }}$ then the null hypothesis rejected. On the contrary, if the score of $F_{\text {value }}<F_{\text {table }}$ then the null hypothesis accepted.

\section{c. T-test}

T-test is used to determine whether each independent variable - either student's perception on roleplay
$\left(\mathrm{X}_{1}\right)$ or learning motivation $\left(\mathrm{X}_{2}\right)$ - one by one contribute significantly to dependent variable speaking skill (Y).

From the T-test, if the score of $t_{\text {value }}>t_{\text {table }}$ then the null hypothesis rejected. On the contrary, if the .score of $t_{\text {value }}<t_{\text {table }}$ then the null hypothesis accepted.

\section{RESULT AND DISCUSSION}

Regression coefficient analysis is a test to the degree of significance of the relationship and the magnitude of the influence of the independent variable $(X)$ on the dependent variable $(\mathrm{Y})$. This test can be done in two ways, first by doing the $\mathrm{F}$ test that aims to determine the magnitude of the regression coefficient or the level of significance of the two independent variables to the dependent variable, while the second way is by test that aims to see the partial regression coefficient of each dependent to the independent variable. From the calculation using SPPS 20.0, it is obtained the regression equation as follows.

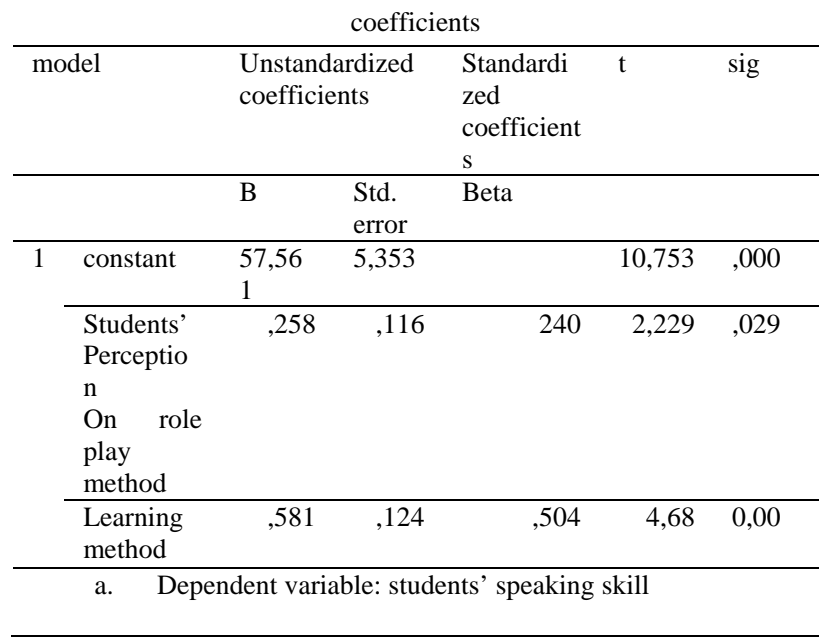

Table 2: Regression Test Result

Based on the table above, it is obtained that:

a. The multiple regression equation for the regression is $\hat{Y}=57.561+0.258+0.581$. This meant that an increase of 1 value on students' perception on role play method(provided that other variable remain the same) will contribute to an increase in Students' speaking skill as much as 0.258 . While an increase of 1 value on learning motivation (provided that other variable remain the same) will contribute to an increase in Students' speaking skill as much as 0.581 .

b. The effect of Students' perception on role play method $\left(\mathrm{X}_{1}\right)$ on Students' speaking skill $(\mathrm{Y})$

The contribution of Students' perception on role play method on Students' speaking skill can be written in the following formula:

$$
\text { DC }=\beta_{x 1 y} \times\left(r_{x 1 y}\right) \times 100 \%
$$


$\mathrm{DC}=0.240 \times 0.177 \times 100 \%=$

$4.25 \%$

The effect of Students' perception on role play method in enhancing Students' speaking skill is $4.25 \%$

c The effect of learning motivation on Students' speaking skill can be written in the following formula:

$$
\begin{aligned}
& \mathrm{DC}=\beta_{x 1 y} \times\left(r_{x 1 y}\right) \times 100 \% \\
& \mathrm{DC}=0.504 \times 0.474 \times 100 \%=23.89 \% \\
& \text { The effect of learning motivation in }
\end{aligned}
$$
enhancing Students’ speaking skillis $23.89 \%$.

Tabel 2: Hasil Uji Regresi

\section{a. Hypothesis Testing}

\section{Hypothesis Testing 1}

The simultaneous effect of Students' perception on role play method (X1) and Learning motivation (X2) toward Students’ speaking skill (Y)

Table 4.10. shows that there is a significant simultaneous effect of students' perception on role play method and learning motivation on Students' speaking skill. This is as confirmed with the value of Fo $=12.355$ and Sig. $0.000<0.05$

\section{Hypothesis Testing 2}

Table 1. revealed that there is a significant effectof students' perception on role play method on Students' speaking skill. This is confirmed with the $\mathrm{t}_{\text {count }}=2.229$ and Sig. $0.029<0.05$.

\section{Hypothesis Testing 3}

Table1 also revealed that there is a significant effect of learning motivation on Students' speaking skill. This is confirmed with $\mathrm{t}=4.687$ and Sig. $0.000<$ 0.05 .

\section{b. Discussion}

1. The effect of Students' perception on role play method (X1) and learning motivation (X2) simultaneously on Students’ speaking skill(Y)

The finding of this research concluded that students' perception on role play method and learning motivation have simultaneouspositive effect on the enhancement of Students' speaking skillFor Junior High School Students in North Jakarta.This meant that the students' perception on role play method and learning motivation have a significant effect on the enhancement of Students' speaking skillFor Junior High School Students in North Jakarta.

Learning a language is meant for the use of language in communication. In the learning of a language there are two categories of language skills: the productive skills, and the receptive skills. Receptive skills refer to the listening and reading, while the productive skills refer to writing and speaking. Both skills are needed in a communication activity. The teachers and students should develop an effective language skills in teaching and learning in order to enhance the use of the language they are learning.

Speaking objectives as in accordance to Brown (2001: 113) is meant for the students to be able to participate in short conversations, provide and answer questions, find ways to convey intents, gathering information from others, and much more. Primary school age children has its own characteristics in the study, compared with adult learners.

The talks involve interaction with one or more speakers. To speak effectively requires good hearing, understanding of the feelings of others, and knowledge of taking a turn or allow others to speak. There are some elements of speaking, namely: the privilege of language; management language, and interaction with others.

Teaching speaking in Junior High School starts from the easiest things to the complex cases, this is to facilitate students in the development process of their speaking ability, especially in learning English, because English is a foreign language which requires different pronunciation and intonation compared to their mother tongue.

Communicating fluently in English allows you to connect with people, participate, and solve problems in society. Fluent communication requires understanding what is being spoken or read and being able to produce fluid, wellpronounced, and accurate messages in return byspeaking and writing (Chrissine Rios, 2013:1).

2. The effect of Students' perception on role play method (X1) on Students' speaking skill(Y).

The finding of this research concluded that students' perception on role play method has a positive effect on the enhancement of Students' speaking skill For Junior High School Students in North Jakarta. This meant that the students' perception on role play method has a significant effect on the enhancement of Students' speaking skill For Junior High School Students in North Jakarta.

English teachers teach English as a tool to communicate orally and in writing. To communicate is to understand and express information, thoughts, feelings, and to develop science, technology, and culture. Ability to communicate in a full understanding is the ability 
to discourse, consisted of the ability to understand and/ or produce spoken text and/ or written which is realized in the four language skills, namely listening, speaking, reading and writing. These skills are used to respond to or create a discourse in public life.

Competency Standards and Competencies Basic SMP states that English subjects is directed to develop these skills (listening, speaking, reading and writing) so that graduates are able to communicate and to produce discourse in English at a certain level of literacy (Badan Standar Pendidikan Nasional, 2006:129).

English literacy levels comprised of performative, functional, informational, and epistemic. At the performance level, people are able to read, write, listen, and speak with the symbols used. At the functional level, people are able to use language to meet the needs of daily living such as reading newspapers, manuals or instructions. At the informational level, people are able to access the knowledge of the language, while at the epistemic level of people able to express knowledge in the target language (Badan Standar Pendidikan Nasional, 2006:129).

One method of learning English is the Role play method. Role play is a kind of motion games in which there is purpose, rules while simultaneously involves excitement. In this method, the students is situated in certain condition outside of the classroom, while the method itself take place in the classroom learning, using the English language. Role Play is often intended as a form of activity in which the learners imagine themselves as if they were outside the classroom and play the role of others when using English.

In Role playing the students are treated as subjects, actively practice speaking (asking and answering in English) with his friends in certain situations. Role-play is challenging; in this method the learners display instantaneously sociopragmatic and pragmalinguistic knowledge in interaction; role-play is fun and motivating; provides the chance for quieter students to express themselves in a more forthright way and the world of the classroom is broadened to include the outside world, thus offering a much wider range of language opportunities (Aliakbari and Jamalvandi, 2010:17).

3. The effect of Learning motivation (X2) on Students' speaking skill(Y)

This research and the theories conclude that learning motivation has a positive effect on the enhancement of Students' speaking skillFor
Junior High School Students in North Jakarta. This meant that learning motivation has a positive effect on the enhancement of Students' speaking skill For Junior High School Students in North Jakarta .

Motivation can be described as something that energizes, directs, and sustains behavior toward a particular goal (Blerkom, 2006:14). Motivation affects whether or not you do your work, which study strategies you decide to use, when you do your work, how long you work on a task, how well you concentrate on it, how much effort you expand doing it, and what you learn from completing the task. The same definition of motivation is also mentioned by Krause, et.al. According to them, motivation can be thought of as an internal process that energizes, directs and maintains behaviour over time. Each of these components is important. 'Energizing' is what starts you off and gets you going. 'Direction' determines what you do, what choices you make or what interests you pursue, while 'maintenance' ensures that this activity continues over time (2010:262).

Motivation is what moves us to action: why we start, go on with or stop an activity; giving a motive to do something; internal processes and external incentives that spur us to satisfy a need; the response we make to challenges and threats in situations where success or failure possible; the marshalling of enthusiasm, confidence and persistence. In other word, motivation is the pilot light of learning (McLean, 2009:7).

The ways in which individuals learn languages and the outcomes of their learning efforts are influenced by a variety of individual psychological factors. These factors, including motivation, affective state and beliefs, describe conditions that are dependent on context or experience and therefore more amenable to change (Benson, 2001:67).

\section{CONCLUSION}

This part will briefly describe the findings of the research that is concluded as following:

1. There is a significant effect of students' perception on role play method and learning motivation simultaneously on Students' speaking skill. This is confirmed with Fo $=12.355$ and Sig. $0.000<0.05$. Variablesstudents' perception on role play method and learning motivation simultaneously contributed as much as $28.2 \%$ toward Students' speaking skill.

2. There is a significant effect of students' perception on role play method on Students' speaking skill. This is confirmed with $\mathrm{t}=2.229$ and Sig. $0.029<0.05$. The students' perception 
on role play method contributes $4.25 \%$ in enhancing Students' speaking skill.

3. There is a significant effect of learning motivation on Students' speaking skill. This is confirmed with $\mathrm{t}=4.687$ and Sig. $0.000<0.05$. Learning motivation Variable contributes23.89\% in enhancing Students’ speaking skill.

\section{REFERENCES}

Aliakbari, M., \&Jamalvandi, B. 2010.The Impact of 'Role Play' on Fostering EFL Learners' Speaking Ability; a Task-Based.Approach. Journal of Pan-Pacific Association of Applied Linguistics , v14 n1 p15-29 .

Arip.M.2009.Hubungan antara Motivasi Belajar dan Pergaulan Peer Group dengan Prestasi Belajar Sosiologi Kelas XI SMA Muhammadiyah 2 GemolongTahunAjaran 2008/2009. Thesis, Universitas Sebelas Maret.

Badan Standar Pendidikan Nasional. 2006 Standar Kompetensi dan Kompetensi Dasar SMP, Badan Standar Pendidikan Nasional.

Bailey. 2005. Adult learning and Literacy.Routledge.

Benson, William Grabe\&Fredricka L. Stoller. 2001. Teaching and Researching Autonomy in Language Learning. Longman

Brown, H.D. 2001. Teaching by Principles.An Interactive Approach to Language Pedagogy. Englewood Cliffs: Prentice Hall.

Dalyono.2009. PsikologiPendidikan, PT. RinekaCipta, Jakarta.

Depdikbud. 2014. Penelitian Tindakan Kelas (Classroom Action Research). Badan Penelitian Dosen LPTK dan Guru Sekolah Menengah. Bandung: Dikti.

Dimyati\&Mudjiono.2004. Belajar Dan Pembelajaran, CetakanKeempat. PT. RinekaCipta

DorathyA.\& S.N. Mahalakshmi.2011.Second Language Acquisition through Task-based Approach - Role-play in English Language Teaching. English for Specific Purposes World ISSN 1682-3257 Issue 33, Volume 11.
Harmer.J. 2007.The changing world of English.In The practice of English Language Teaching. Cambridge:UK, Pearson Longman

Joyce\&Marsha Weil. 2007. Models of teaching.Prentice-Hall.

Kumaravadivelu.B. 2006. Understanding Language Teaching: From Method to Post-method ESL and applied linguistics professional series.LEA'S Communication Series. Lawrence Erlbaum Associates.ISBN.

McLean.A. 2009.Motivating Every Learner. SAGE Publications Ltd.

Priyatno.D. 2010. Teknik Mudah dan Cepat Melakukan Analisis Data : Penelitian dengan SPSS dan Tanya Jawab Ujian Pendadaran. Gaya Media, Yogyakarta .2009."SPSS untuk Analisis Korelasi dan Regresi", Cetakan Pertama, Yogyakarta: GavaMedia, Yogyakarta

Richards, Jack, John Platt, and Heidi Weber.1985.Longman Dictionary Of Applied Linguistics. Harlow, Essex, England: Longman.

Rios. C. 2013. Improve Your Fluency. Kaplan University Writing Center

Rusman.2012. Model Model Pembelajaran. Depok: PT Raja grafindo Persada

Syamsuddin, Makmun. 2003. Psikologi pendidikan: Perangkat Sistem Pengajaran Modul, PT. Remaja Rosdakarya, Bandung.

Stipek. D.2002. Motivation to learn: From theory to practice (4th edition).Needham Heights.

Sri Rahayu, P. 2009. MetodePenelitianPendidikan, Jakarta: STKIP Press

Van Blerkom.D.L 2006. Orientation to College Learning.Wadsworth Publishing.

Yamin. R. 2012.The effectof Using Role-Play on Iranian EFL Learners' speaking ability. Department of English Language,Islamic Azad University. 